\title{
Praktek Monopoli Pos Dan Kargo Yang Dikelola Oleh Pengelola PT. Angkasa Pura II (Persero)
}

\author{
Mita Rahmawitri $^{1 *}$, Sylvana Murni Deborah Hutabarat ${ }^{2}$ \\ 12 Fakultas Hukum, Universitas Pembangunan Nasional "Veteran" Jakarta \\ *Korespondensi: mita.rahmawitri@gmail.com
}

Info Artikel

Diterima : 8 Jul 2020 Direvisi : 14 Ags 2020 Disetujui : 28 Ags 2020 Diterbitkan : 7 Des 2020

DOI: https://doi.org/10.31599/krtha.v14i2.221

Keywords : $\quad$ Businesss Competition, Price Fixing Agreement, Freight Container

Abstract : Indonesia is one of the largest archipelago countries in the world, with a huge population with trade potential and also business assistance in all economic sectors that can provide welfare for the people. The Trade Sector can be accessed through Air Transportation which can maximize and save time in distribution for business people who do. With the existence of the trade sector, PT Angasa Pura II (Persero) as a State-Owned Enterprise in the field of Airport Business Entity provides airport services which include incorrect goods and postal services provided and provide or provide terminals for freight and postal services. But in the process of providing these facilities, PT Angkasa Pura II (Persero) at Kualanamu Airport in Medan is a place of trade monopoly practice, the place of practice is called Law Number 5 of 1999 concerning Probibition of Monopolistic Practices and Unfair Business Competition. In the discussion of this Journal, the research method that will be used in this research is Normative Legal (juridical normative) research where this method is in accordance with the reporting that will be discussed in relation to Trade Monopoly Practices conducted at PT Angasa Pura II (Persero) at Kualanamu Airport Medan.

Kata kunci : Sektor Perdagangan, Praktek Monopoli, penyediaan fasilitas

Abstrak : Indonesia adalah salah satu Negara kepulauan terbersar di dunia, dengan jumlah populasi penduduk yang besar sehingga memiliki potensi Perdagangan dan juga pelaku usaha disemua sektor perekonomian yang dapat memberikan kesejahteraan bagi rakyat. Sektor Perdangangan tersebut dapat terhubung melalui Transportasi Udara dimana dapat memaksimalkan dan menghemat waktu dalam pendistribusian kepada pelaku usaha yang melakukannya. Dengan adanya sektor perdagangan tersebut maka PT Angkasa Pura II (Persero). Sebagai Badan Usaha Milik Negara di bidang Badan Usaha Bandar Udara memberikan pelayanan jasa kebandarudaraan berupa pelayanan jasa barang dan pos yang salah satunya adalah penyediaan dan/atau pengembangan fasilitas terminal untuk pelayanan angkutan kargo dan pos. Namun dalam proses penyediaan fasilitas tersebut PT Angkasa Pura II (Persero) di bandar udara Kualanamu Medan terdapat praktek monopoli perdangan, dimana praktek tersebut melanggar Undang-Undang Nomor 5 Tahun 1999 tentang Larangan Praktek monopoli dan Persaingan Usaha Tidak Sehat. Dalam pembahasan Jurnal ini, Metode penelitian yang akan digunakan dalam penelitian ini adalah penelitian Hukum Normatif (yuridis normatif) dimana metode tersebut sesuai dengan kasus yang akan dibahas terkait Praktek Monopoli Perdangan yang dilakukan pada PT Angkasa Pura II (Persero) Bandar Udara Kualanamu Medan. 


\section{PENDAHULUAN}

Indonesia merupakan sebuah negara kepulauan yang saling terhubung antara satu dengan yang lainnya. Terjalinnya hubungan antar pulau, salah satunya melaui jalur perdagangan. Untuk memudahkan terjalinnya perdagangan salah satunya dapat menggunakan transportasi udara. Perdagangan itu sendiri merupakan suatu usaha yang digunakan untuk memperoleh keuntungan sebesar-besarnya. Sehingga, dalam proses perdagangan sering ditemui persaingan antar pelaku usaha.

Arti kata persaingan adalah perihal bersaing dan usaha memperlihatkan keunggulan masing-masing yang dilakukan oleh perseorangan (perusahaan, negara) pada bidang perdagangan, produksi, persenjataan, dan sebagainya. ${ }^{1}$ Salah satu bentuk tindakan persaingan adalah monopoli. Pada dasarnya persaingan bersifat mendesentralisasikan kekuatan ekonomi, sementara monopoli bersifat memusatkan kekuatan pada satu orang atau satu kelompok. ${ }^{2}$ Akibat adanya pemusatan kekuatan ini, monopoli dianggap sebagai kondisi yang negatif. Hal ini dikarenakan pada saat kondisi monopoli terbuka kemungkinan cukup besar bagi penyimpangan kekuatan monopoli. ${ }^{3}$ Ketentuan mengenai monopoli dan persaingan usaha tidak sehat diatur dalam Undang-undang Nomor 5 Tahun 1999 yang disahkan pada tanggal 5 Maret 1999.

Perkiraan terkait terjadinya praktek monopoli yang dilaksanakan olehn PT Angkasa Pura II (Persero) di Bandara Internasional Kualanamu Medan. PT AP II merupakan salah satu Badan Usaha Milik Negara yang ditetapkan sebagai Badan Usaha Bandar Udara yang bergerak dalam bidang usaha pelayanan jasa kebandarudaraan dan pelayanan jasa terkait bandar udara diwilayah Indonesia Barat. Di Bandar Udara Kualanamu, PT Angkasa Pura II (Persero) memberikan pelayanan jasa kebandarudaraan berupa kegaiatan pelayanan jasa barang dan pos dimana salah satunya adalah melakukan pengembangan fasilitas yang terdapat di terminal untuk meningkatkan pelayanan angkutan dibidang jasa kargo dan pos. $^{4}$

PT Angkasa Pura II (Persero) memberlakuan Daerah Keamanan Terbatas di Bandar Udara Kualanamu pada 1 Mei 2014, berdasarkan Pasal 334 ayat (1) Undang-undang Nomor 1 Tahun 2009 tentang Penerbangan, orang perseorangan, kendaraan, kargo dan pos yang akan memasuki Daerah Keamanan Terbatas wajib memiliki izin masuk daerah

\footnotetext{
1 Arti kata Persaingan, <https://kbbi.web.id/saing>, diakses pada tanggal 24 Februari 2020 pukul 23:16

2 Arie Siswanto, Hukum Persaingan Usaha, cet 2, (Bogor: Ghalia Indonesia, 2004), Hal. 18

${ }^{3}$ Ibid., Hal. 19.

${ }^{4}$ Putusan KPPU No. 03/KPPU-I/2017., Hal. 175
} 
terbatas dan dilakukan pemeriksaan keamanan. Daerah Keamanan Terbatas merupakan daerah tertentu yang berada di dalam atau di luar bandar udara yang ditetapkan sebagai daerah yang memiliki tingkat resiko tinggi, dan digunakan dalam kepentingan penerbangan, penyelenggara bandar udara, dan kepentingan lain dimana daerah tersebut dilakukan pengawasan dan pemeriksaan keamanan. ${ }^{5}$ Izin masuk ke Daerah Keamanan Terbatas untuk wilayah bagian luar gudang kargo atau halaman gudang kargo berupa Surat Muatan Udara (SMU) dan Pas Bandar Udara.

Penelitian ini membahas tentang praktek monopoli yang dilakukan di Bandara Internasional Kualanamu Medan, yang bermula pada PT Angkasa Pura II (Persero) yang melaksanakan sistem Daerah Keamanan Terbatas, yang berlaku pada 1 May 2014. Dengan pelaksanaan Daerah Keamanan Terbatas, maka diatur persyaratan memasuki Daerah Keamanan Terbatas diwajibkan memiliki izin masuk dan yang tidak mempunyai dapat menggunakan pelayanan jasa kawasan pergudangan Lini 2. Pengambilan kargo di Lini 2 ditarik tariff senilai Rp 350 per kg, dan administratiff Rp 5.000 per SMU. Dengan adanya hal itu maka berakibat bertambahnya biaya dan ruang pengambilan barang yang tidak menguntungkan konsumen. tanggal 1 september 2015, Regulated Agent (RA) yang dikelola PT Apollo Kualanamu mulai beroperasi. Setelah berlakunya RA sudah tidak ada lagi pemeriksaan $x$-ray di Lini 2, namun barang masih dikarenakan biaya Rp $800 / \mathrm{kg}$, dengan adanya pengalihan pekerjaan untuk outgoing kargo di Lini 2 ke RA. Akibatnya menurun volume pekerjaan dari Lini 2.

\section{METODE PENELITIAN}

Metode penelitian hukum adalah suatu cara yang sistematis dalam melakukan sebuah penelitian. ${ }^{6}$ Peter Mahmud menjelaskan, Penelitian hukum merupakan cara untuk menentukan aturan yang berguna menanggapi kasus hukum yang sedang dihadapi. ${ }^{7}$ Metode penelitian yang digunakan, yaitu:

a. Jenis Penelitian

Metode penelitian menggunakan penelitian hukum normatif (yuridis normatif). Untuk itu diperlukan penelitian yang merupakan suatu rencana pokok dalam pengembangan ilmu pengetahuan. Menurut Soerjono Soekanto, pendekatan yuridis

\footnotetext{
5 Peraturan Menteri Perhubungan Nomor 33 Tahun 2015 tentang Pengendalian Jalan Masuk ke Daerah Keamanan Terbatas. Pasal 1 angka 7.

${ }^{6}$ Abdulkadir Muhammad, 2004. Hukum dan Peneliitian Hukum. PT.Citra Aditya Bakti. Bandung. Hal.57

${ }^{7}$ Peter Mahmud Marzukii, 2011. Penelitian Hukum. Kencana Prenada Media Group. Jakarta. Hal. 35.
} 
normatif merupakan penelitian hukum yang dilakukan dengan meneliti bahan pustaka atau/atau data sekunder sebagai bahan dasar untuk diteliti dengan melakukan penelusuran terhadap peraturan-peraturan dan literatur-literatur yang berkaitan dengan permasalahan yang diteliti. ${ }^{8}$ Maksud dari dilakukannya penelitian ini ialah untuk memberikan argumentasi hukum dalam menjadi penentu telah benar atau salah suatu peristiwa serta bagaimana baiknya suatu peristiwa tersebut di mata hukum. ${ }^{9}$

b. Pendekatan Masalah

Dalam penelitian ini melakukan pendekatan dengan menggunakan pendekatan undang-undang dan pendekatan kasus. Pendekatan perundangan-undangan dilakukan dengan menjelaskan semua undang-undang dan peraturan yang terkait dengan isu hukum yang sedang diteliti. Pendekatan kasus dilakukan dengan menjelaskan kasus-kasus terkait dengan isu yang sedang dijumpai dan telah memiliki kekuatan hukum tetap.

c. Sumber Data

- Sumber Bahan Hukum Primer

Sumber bahan hukum primer yang dipergunakan dalam penelitian penelitian ini adalah sebagai berikut;

1) Putusan KPPU No. 03/KPPU-I/2017;

2) Undang-undang Nomor 5 Tahun 1999 tentang Praktek Monopoli dan Persaingan Usaha Tidak Sehat;

3) Undang-undang Nomor 1 Tahun 2009 tentang Penerbangan

4) Peraturan Menteri Perhubungan Nomor 36 Tahun 2014 tentang Tata Cara dan Produsen Tariff Jasa Kebandarudaraan;

5) Beberapa peraturan dan pedoman KPPU.

- Sumber Bahan Hukum Sekunder

Sumber bahan hukum sekunder yang digunakan dalam iَsepepipenelitian ini ialah bahan - bahan pustaka yang membahas dan menjelaskan bahan hukum primer yang dapat berupa buku teks, jurnal hukum, majalah hukum, pendapat

\footnotetext{
${ }^{8}$ Soerjono Soekanto \& Sri Mamudji, Penelitian Hukum Normatif (Suatu Tinjauan Singkat), Rajawali Pers, Jakarta, 2001, Hal. 13-14.

9 Mukti Fajar and Yulianto Achmad, Dualisme Penelitian Hukum Normatif Dan Empiris, Cetakan IV (Yogyakarta: Pustaka Pelajar, 2017), Hal. 36.
} 
para pakar serta berbagai macam referensi yang berkaitan dan bersifat sebagai

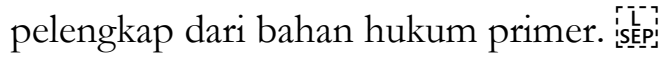

- Sumber Bahan Hukum Tersier

Sumber bahan hukum tersier dalam penelitian ini yaitu bahan- bahan lainnya yang memberikan informasi bahan hukum primer dan bahan hukum sekunder, berupa kamus hukum, media internet, buku petunjuk atau buku pegangan.

\section{d. Teknik Analisis Data}

Metode atau teknik analisi yang digunakan adalah teknik analisis deskriptif. Analisis deskriptif merupakan penelitian yang dilakukan untuk mengetahui ketepatan variabel mandiri, baik pada satu variabel atau lebih tanpa adanya pembandingan. ${ }^{10}$

Adapun tahapan yang dilakukan, pertama mengkaji fakta hukum dan mengurangi kegiatan yang tidak selaras dalam menentukan kasus hukum yang akan dipecahkan. Kedua, mengakumulasi bahan hukum dan bahan non hukum. Ketiga, mencari kajian atas kasus hukum yang diteliti sesuai buku, jurnal atau pendapat ahli. Keempat, membuat kesimpulan.

\section{PEMBAHASAN}

\section{A. Praktek Monopoli Dilaksanakan Pengelola Terhadap Pos Dan Kargo}

Dalam berjalannya suatu perusahaan tidak dapat dipungkiri dapat timbul permasalahan-permasalahan yang salah satunya adalah praktek monopoli. Praktek Monopoli merupakan pemusatan kekuatan ekonomi yang dilakukan oleh satu atau lebih pelaku usaha yang mengakibatkan dikuasainya produksi dan/atau pemasaran atas barang dan/atau jasa tertentu sehingga menimbulkan persaingan usaha tidak sehat dan dapat merugikan kepentingan umum. ${ }^{11}$ Monopoli dalam sistem ekonomi Indonesia tidak dikehendaki, hal ini mengakibatkan, perusahaan bersangkutan dapat mengendalikan pemasaran dan dapat menentukan harga maupun pasokan barang. Monopoli yang timbul tidak selalu akibat dari liberalisasi dalam ekonomi, karena pemerintah juga membutuhkan

\footnotetext{
${ }^{10}$ Sugiyono, 2009, Metode Penelitian Kuantitatif, Kualitatif dan R\&D, Bandung : Alfabeta. Hal. 35

${ }^{11}$ Undang-undang Nomor 5 Tahun 1999 tentang Larangan Praktek Monopoli dan Persaingan Usaha Tidak Sehat, Pasal 1 Angka 2
} 
suatu pengaturan, sehingga penyediaan barang jasa mudah untuk dikendalikan. ${ }^{12}$

Praktek monopoli yang terjadi pada pelayanan angkutan kargo pos melewati Bandar Udara Kualanamu medan yang dilakukan oleh pengelola. Kasus bermula pada saat PT Angkasa Pura II (Persero) yang memberlakukan sistem Daerah Keamanan Terbatas, yang berlaku pada 1 May 2014. Dengan pelaksanaan Daerah Keamanan Terbatas, maka diatur persyaratan memasuki Daerah Keamanan Terbatas diwajibkan memiliki izin masuk dan yang tidak mempunyai dapat menggunakan pelayanan jasa kawasan pergudangan Lini 2. Pengambilan kargo di Lini 2 ditarik tariff senilai Rp 350 per kg, dan administratif Rp 5.000 per SMU. Dengan adanya hal tersebut maka berakibat bertambahnya tariff dan ruang pemungutan barang dimana tidak menguntungkan pengguna jasa. PT AP II juga masih menentukan tariff penerimaan sebesar Rp 800,00 per kg. Besarnya biaya pengambilan kargo di Lini 2, disebabkan karena harga sewa sewa gudang dan adanya contribution fee yang harus dibayarkan kepada airlines. Contribution fee ini merupakan unsur penilaian dalam pemilihan mitra melalui tender.

Adanya kecurigaan bahwa persyaratan yang dibuat oleh PT AP II hanya sebagai alasan untuk mempertahankan penyewaan gudang di Lini 2, karena jika Lini 2 tidak memiliki pekerjaan untuk penarikan kargo, mereka tidak akan menyewa gudang di kawasan pergudangan Lini 2. Terdapat dugaan lain dimana PT AP II terjadi penyimpangan kewenangan, dimana menerapkan syarat-syarat yang diduga untuk menghalangi konsumen dalam mendapatkan barang dan/atau jasa dengan kualitas yang baik. Selain itu di Bandar Udara Kualanamu tidak terdapat Badan Usaha Bandar Udara selain PT AP II dalam hal pelayanan jasa kebandarudaraan.

Pada tanggal 10 September Regulated Agent (RA) PT Apollo Kualanamoo mulai beroperasi. PT AP II menghentikan pemeriksaan kargo dengan x-ray di terminal kargo (Lini 1) dan hanya menerima kargo outgoing yang telah diperiksa di Regulated Agent (RA). Sejak diberlakukannya Regulated Agent (RA) terdapat perubahan sebagai berikut:

12 Zuhro Puspitasari, "Rekonsepsi Pengecualian Monopoli yang diselenggarakan oleh Badan Usaha Milik Negara dalam Hukum Persaingan Usaha di Indonesia", Jurnal Panorama Hukum, Vol. 2, No. 2, 2017, Hal. 231 


\begin{tabular}{lll}
\hline & \multicolumn{1}{c}{ Sebelum RA } & \multicolumn{1}{c}{ Sesudah RA } \\
\hline Operator di Lini 1 & PT AP II & PT Angkasa Pura II (persero) \\
\hline Operator di Lini 2 & Lini 2 & PT Apollo Kualanamoo \\
\hline Biaya Lini 1 & Rp 800/kg + PPN 10\% & Rp 800/kg + PPN 10\% \\
\hline Biaya Lini 2/RA & Rp 350/kg + PPN 10\% & Rp 1.000/kg + PPN 10\% \\
\hline Waktu pemeriksaan & 2 jam & 5 jam \\
\hline
\end{tabular}

(Tabel.1: perubahan yang terjadi setelah Regulated Agent diberlakukan)

Penambahan biaya terhadap pengiriman kargo dengan berlakuknya RA yaitu sebesar Rp 650,00 perkg. Dengan adanya pengalihan pekerjaan untuk outgoing kargo dari Lini 2 ke Regulated Agent (RA), mengakibatkan menurunnya volume pekerjaan di Lini 2. Namun PT AP II tidak menanggapi permintaan penurunan tariff sewa ruangan dan pergudangan di Bandar Udara Kualanamu. Padahal tariff sewa ruangan dan pergudangan tidak sesuai dengan fasilitas yang diterima antara lain atap perkantoran yang bocor, lift sudah tidak berfungsi, dan kebersihan yang kurang terjaga, namun Lini 2 tidak punya pilihan lain karena persyaratan untuk menjadi mitra dari PT AP II adalah wajib menyewa gudang di public area (Lini 2). ${ }^{13}$

Praktek monopoli merupakan pemusatan kekuatan ekonomi oleh satu atau lebih pelaku usaha yang mengakibatkan dikuasainya produksi dan/atau pemasaran barang atau jasa tertentu sehingga dapat menimbulkan persaingan usaha tidak sehat dan dapat merugikan kepentingan umum. Unsur-unsur dari praktek monopoli, yaitu terjadinya pemusatan kekuatan ekonomi pada satu atau lebih pelaku usaha, terdapat penguasaan atas produksi atau pemasaran barang atau jasa tertentu, terjadi persaingan usaha tidak sehat, dan tindakan yang dapat merugikan kepentingan umum. Pada teorinya penguasaan yang dilarang adalah penguasaan yang mengakibatkan persaingan tidak sehat dan dapat merugikan kepentingan umum. ${ }^{14}$

Sesuai dengan Pasal 233 ayat (1) huruf a Undang-undang Nomor 1 Tahun 2009 telah memberikan hak eksklusif kepada Badan Usaha Bandar Udara ketika memperoleh izin dari Mentri Perhubungan untuk memberikan pelayanan di bidang jasa kebandarudaraan. Dapat dikatakan bahwa PT AP II memiliki hak eksklusif, dimana hak tersebut diberikan

\footnotetext{
13 Putusan KPPU No 03/KPPU-I/2017 tentang Gambaran Umum dan Permasalahan

${ }^{14}$ Dr. Andi Fahmi Lubis, SE, ME, dkk. Buku Teks Hukum Persaingan Usaha Edisi Kedua, Jakarta: KPPU, 2017, Hal. 139
} 
oleh pemerintah kepada pelaku usaha tertentu, terpangkut hasil produksi dan/atau penyebaran barang dan/atau jasa dimana dapat memenuhi kehidupan masyarakat serta beberapa cabang produksi penting bagi negara, diatur dalam undang-undang dan dijalankan oleh badan/lembaga yang ditunjuk oleh pemerintah. PT AP II merupakan agen tunggal dan tidak terdapat Badan Usaha Bandar Udara lain dalam penyediaan fasilitas pelayanan jasa pos dan kargo di Bandar Udara Kualanamu.

Salah satu penyimpangan posisi monopoli yang dilakukan PT AP II adalah adanya penetapan tariff pengiriman dan penerimaan pos dan kargo yang tidak wajar. ketentuan tariff tertuang di pasal 9 ayat (1) Peraturan Menteri Perhubungan Nomor 36 Tahun 2014, "Tariff Jasa Kargo Dan Pos Pesawat Udara Adalah besaran satuan biaya yang dibayarkan oleh pemilik dan penerima kargo dan pos atas pelayanan area/wilayah kargo dan pos di bandar udara yang dihitung selama berada dalam area/wilayah kargo nandar udara."

Dengan adanya penetapan tariff pengiriman dan penerimaan kargo di Bandar Udara Kualanamu yang tidak wajar dan berubah-ubah karena berubahnya pemberlakuan sebelum Daerah Keamanan Terbatas sampai pemberlakuan Regulated Agent (RA), membuat konsumen menjadi bingung dan merasa dirugikan. Kemudian syarat untuk pengambilan kargo pengiriman dan penerimaan harus melalui Lini 2 membuat konsumen tidak memiliki banyak pilihan karena tingginya harga sewa yang harus ditanggung. Konsumen akan memilih untuk menarik kargonya kembali, karena kenaikan tariff ini tidak ada manfaat apapun bagi konsumen.

Penyelesaian perkara ini diselesaikan oleh Komisi Pengawas Persaingan Usaha (KPPU). KPPU bertugas untuk mengawasi kegiatan perjanjian, kegiatan usaha dan/atau tindakan pelaku usaha, serta penilaian terhadap ada atau tidak adanya penyimpangan posisi dominan yang tidak dapat mengakibatkan terjadinya praktek monopoli dan/atau persaingan usaha tidak sehat, mengambil tindakan sesuai dengan wewenang komisi, memberikan saran dan pertimbangan terhadap kebijakan pemerintah yang berkaitan dengan pratik monopoli dan persaingan usaha tidak sehat, menyusun pedoman dan/atau publikasi yang berkaitan dengan Undang-undang, dan memberikan laporan secara berkala atas hasil kerja Komisi kepada Presiden dan Dewan Perwakilan Rakyat. Sebagai lembaga yang independen, artinya KPPU diluar dari kekuasaan pemerintah dan pihak lainnya, KPPU memiliki kewenangan untuk mengawasi persaingan usaha dan memberikan sanksi. Sanski berupa hukuman administratif, karena sanksi pidana merupakan wewenang pengadilan. 
Peraturan pelaksanaan proses penyelesaian sengketa persaingan usaha diatur dengan Surat Keputusan Nomor 5/KPPU/KEP/IX/2000 tentang Tata Cara Penyampaian Laporan dan Penanganan Dugaan Pelanggaran Undang-undang Nomor 5 Tahun 1999. Dari analisis terhadap data dapat disimpulkan bahwa kekuatan hukum putusan KPPU dapat dilakukan dalam penyelesaian kasus Monopoli terkait Penyediaan Pelayanan Jasa Pos dan Kargo oleh PT AP II di lingkungan Bandara Internasional Kualanamu.

Dengan adanya Laporan terkait praktek Monopoli tersebut KPPU melakukan penelusuran terkait kasus tersebut, dan memperoleh bahwa bukti-bukti yang ada cukup jelas dan lengkap untuk dikatakan melakukan kesalahan di dalam Pasal 17 Undang-undang Nomor 5 Tahun 1999. Memberikan hukuman Administratif dengan membayar denda sebesar enam milyar lebih yang harus disetor ke Kas Negara, serta menurunkan tariff pengiriman kargo pos mempertimbangkan seluruh aktivitas hilang setelah digantikan oleh Regulated Agent (RA) lalu menempatkan kembali proses pengumpulan kargo pos di Bandar Udara Kualanamu tidak melawati Lini 2.

Asumsi pelanggaran pada Pasal 17 ayat (1) dan ayat (2) Undang-undang No. 5 Tahun 1999 tentang Praktek Monopoli, yang dilakukan pengelola didalam pelayanan memberikan fasilitas dan akses terminal untuk kargo pos melalui Bandar Udara Kualanamu. Pasal 17 Undang-undang No. 5 Tahun 1999, membahas tentang larangan penggarap usaha dalam melaksanakan penguasaan produksi dan/atau pemasaran barang, yang berakibat terjadinya praktek monopoli dan/atau persaingan usaha tidak sehat. Penggarap usaha dimaksud, apabila melaksanakan pemasaran barang hasil produksi dan/atau jasa yang bersangkutan belum ada subtitusinya, mengakibatkan penggarap usaha lain tidak bisa masuk ke dalam persaingan usaha di bidang barang dan/atau jasa yang sama, dan merupakan satu bahkan beberapa beberapa penggarap usaha yang menempati melebihi dari 50\% (lima puluh persen) pasar satu jenis hasil barang dan/atau jasa.

Pada pokoknya bagian yang terdapat dalam Pasal 17 Undang-undang Nomor. 5 Tahun 1999, yaitu menguasai atas suatu produk, melakukan pemasaran suatu produk, dan dapat berakibat terjadinya praktek monopoli serta persaingan usaha tidak sehat. ${ }^{15}$

Untuk membuktikan terjadi atau tidak suatu pelanggar. Majelis Komisi menimbang unsur-unsur sebagai berikut:

15 Ibid., Hal. 138 


\section{Pelaku Usaha}

Penggarap usaha merupakan perseorangan atau badan usaha yang berwujud badan hukum maupun bukan badan hukum. Dibentuk, berkedudukan, dan melaksanakan aktivitas di Indonesia, baik individual maupun kelompok berdasarkan perjanjian. PT AP II adalah pelaku usaha dalam kasus ini, dengan ini unsur pelaku usaha terpenuhi.

\section{Penguasaan}

Penguasaan merupakan kewenangan sah suatu pasar bersangkutan oleh satuu atau penggarap usaha sehingga menetapkan, mengkontrol tarif barang dan/atau jasa pada pasar(market). Pasar bersangkutan dalam perkara ini berkaitan dengan pelaksanaan pemberian jasa fasilitatif terminal untuk melakukan pelayanan pos dan kargo dan jasa pelayanan pergudangan di Bandar Udara Kualanamu. Dalam hal imi PT AP II terbukti menguasai pasar karena memperoleh hak eksekutif dari Pemerintah, dengan ini unsur penguasaan terpenuhi.

\section{Barang dan Jasa}

Barang merupakan benda Nampak ataupun tidak, berpindah ataupun tidak, dapat diperdagangkan, digunakan, oleh pelanggan dan/atau pelaku usaha. Dan jasa merupakan fasilitas berupa pekerjaan diberikan kepada masyarakat. Objek dalam perkara ini ialah jasa penyediaan fasilitas untuk pelayanan pos dan kargo serta jasa perdagangan, demikian ini barang dan jasa terpenuhi.

\section{Praktek Monopoli}

Praktek monopoli merupakan suatu focus pada kekuasaan di bidang perekonomian yang dilakukan oleh satuu maupun lebih pengarap usaha, dapat memicu terjadinya penguasaan produksi hasil dan/atau pemasaran barang dan/atau jasa tertentu. Praktek monopoli yang dilaksanakan pengelola terkait pengelolaan penyediaan pelayanan fasilitas jasa pos kargo di Bandar Udara Kualanamu, yaitu dalam bentuk penetapan tariff yang melampaui batas yang menyebabkan kerugian pada konsumen. Dengan ini unsur pratek monopoli terpenuhi.

\section{Persaingan usaha tidak sehat}

Persaingan usaha tidak sehat adalah kompetisi antar pelaku usaha dalam mengembangkan kegiatan produksi dan/atau pendistribusian barang dan/atau jasa, dilakukan dengan cara melawan ketentuan hukum yang dapat menghentikan persaingan usaha. Dengan adanya fakta penetapan tariff pemberian kargo dan pos kapal udara dimana 
tinggi dan adanya biaya pelayanan gudang yang tidak sesuai dengan keadaan yang sebenarnya serta adanya pendapatan ganda yang diperoleh, memberikan merugikan pelanggan yang dibayar melebihi ketentuan. Dengan ini unsur persaingan usaha terjadi secara tidak sehat terpenuhi.

Untuk membuktikan terhadap kesalahan terkait Pasal 17 Undang-undang No. 5 Tahun 1999 dasarnya adalah pembuktian posisi monopoli dan praktek monopoli. KPPU dalam judifikasi adanya kesalahan terkait Pasal 17, menggunakan konsep pendekatan rule of reason yang dibagi beberapa tahap, yakni penjelasan pasar bersangkutan, terdapatnya pemastian letak monopoli, kemudian persepsi praktek monopoli yang dilakukan mempunyai potensi posisi monopoli serta menimbulkan dampak negatif.

\section{B. Tanggung Jawab PT AP II Sebagai Pengelola Dalam Akibat Adanya Praktek Monopoli Pos Dan Kargo}

Pada pokoknya tanggung jawab merupakan kapasitas yang harus dimiliki seseorang atau perusahaan untuk memberikan respon terhadap berbagai hal yang diminta oleh pihak lain. Terdapat tigaa macam tanggung jawab, yaitu dalam bidang ekonomi, hukum, dan sosial.

Berdasarkan 3 (tiga) jenis tanggung jawab tersebut, disimpulkan yakni dalam perkara ini PT AP II telah melanggar tanggung jawab hukum karena dalam melaksanakan kegiatannya, perusahaan korporasi wajib mengikuti peraturan perundang-undangan yang telah ditetapkan sebagai rasa tanggung jawab terhadap hukum. Hukum dan peraturan yang dibuat dikhusukan untuk pengoperasian suatu perusahaan yang dibutuhkan oleh masyarakat. Selain itu dapat mendukung terciptanya bisnis yang adil bagi semua pelaku bisnis, dan tidak menimbulkan kerugiann antar pesaing pelaku bisnis.

Kenaikan harga yang relatif tinggi dibandingkan dengan pengiriman kargo melalui jenis transportasi lain, dipicu oleh adanya penerapan DKT dan Regulated Agent. Tidak berdampak pada perpindahan konsumen menggunakan jenis transportasi lain dalam melakukan pengiriman kargo, karena tidak terdapat pilihan lain bagi konsumen yang akan mengirimkan maupun menerima kargo melalui pesawat udara di daerah kota Medan dan Kabupaten/kota disekitarnya selain melalui Bandara Udara Kualanamu dan harus menggunakan fasilitas terminal kargo milik PT AP II yang dikelola oleh operator terminal yang telah ditunjuk.

Praktek monopoli tersebut juga dinilai telah mengakibatkan dampak kepada kepentingan umum karena logistik yang tinggi akan mempengaruhi perekonomian nasional karena pengguna jasa tersebut akan memberikan beban kembali tambahan tariff 
tersebut kepada shipper/pembawa kargo. Di satu sisi, kargo yang dikirimkan dapat berupa barang konsumsi maupun barang modal/bahan baku produksi. Jika kargo yang dikirim adalah barang modal/bahan baku produksi maka akan berdampak terhadap kenaikan secara tidak langsung barang lain yang diproduksi tetapi juga akan berdampak langsung terhadap barang konsumsi yang dikirimkan.

KPPU menilai bahwa dengan demikian PT AP II telah melakukan penyimpangan posisi monopoli dan pelanggaran dengan mengenakan harga yang merugikan masyarakat. PT AP II hanya mengambil keuntungan sendiri secara sepihak tanpa memperhatikan kebutuhan masyarakat. Oleh karena itu, berdasarkan pendekatan rule of reason yang menganalisis dampak terhadap persaingan, terbuktilah bahwa apa yang dilakukan PT AP II merupakan Praktek monopoli tidak menguntungkan kepentingan umum dan karenanya dilarang. ${ }^{16}$

Pada proses ini menerapkan pendekatan rule of reason dimana ahrus melewati proses pembuktian yang dimulai dengan cara menempatkan pengertian relevant market. Dimana jika dihitung, dinilai dan diputuskan implikasi terjadinya persaingan akibat perilaku berdasarkan ukuran (pangsa) pasar dan pasar terkait (the relevant market). Apabila pasar dimaskud adalah kecil dan perusahaan terdapat ddialam pemantauan mempunyai pasar dan jangkauan luas daripada pasar tersebut, perusahaan dianggap lebih mendominasi. ${ }^{17}$

Rule of reason adalah pilihan yang tepat untuk menentukan suatu tindakan penyidikan, menganalisa sangat dibutuhkan dalam menentukan praktek yang dapat menghambat persaingan. Pengadilan wajib mengambil keputusan yang memberikan pengaruh yang paling menguntungkan bagi masyarakat.

Berdasarkan data kesimpulan investigator serta hasil persidangan PT AP II terbukti melakukan pelanggaran terhadap Pasal 17 ayat (1) dan (2) Undang-undang Nomor 5 Tahun 1999 dan merupakan pelaku usaha tunggal yang mendapatkan hak ekslusif untuk melakukan jasa penyedian/fasilitas terminal untuk pelayanan angkutan kargo dan pos di bandar udara kualanamu serta satu-satunya penyedia jasa fasilitas pergudangan Lini 2 di Bandar Udara kualanamu dengan begitu unsur barang dan/atau jasa yang berkaitan tidak ada penukarannya, karena jika dilihat penggarap usaha lainnya tidak bisa masuk ke persaingan usaha barang dan/atau jasa yang sama. Dengan demikian PT AP II

\footnotetext{
${ }^{16}$ Indra Sanjaya, "Penerapan Pendekatan Rule Of Reason Oleh Kppu Dalam Dugaan Pengenaan Harga Eksesif (Studi Kasus Putusan KPPU Nomor Perkara 03/Kppu-I/2017)”, Junal Ilmu Sosial dan Pendidikan Vol. 4 No. 2, 2020, Hal. 132.

${ }^{17}$ Ida Bagus Kade Benol Permadi dan A.A Ketut Sukranatha, "Konsep Rule of Reason Untuk Mengetahui Praktek Monopoli” Jurnal Hukum. Hal. 4
} 
menghasilkan keuntungan 50\% serta menjadi perusahaan tunggal yang mengakibatkan perusahaan lain takut bersaing.

Serta berdasarkan Putusan yang dijatuhkan oleh Majelis Komisi berdasarkan pedoman Pasal 47 UU No. 5/1999 tentang Tindakan Administratif, PT AP II wajib membayar denda sebesar enam milyar yang harus disetor ke Kas Negara, serta menurunkan beban pengiriman kargo dan pos dengan mempertimbangkan seluruh aktivitas yang musnah ketika digantikan regulated agent (RA) menempatkan kembali cara pengambilan kargo dan pos di Bandar Udara Kualanamu tanpa melewati Lini 2.

\section{KESIMPULAN}

Penyimpangan monopoli yang dilaksanakan PT Angkasa Pura II (persero) adalah adanya penetapan tariff pengiriman dan penerimaan pos dan kargo yang tidak wajar. ketentuan tariff tertuang di pasal 9 ayat (1) Peraturan Menteri Perhubungan Nomor 36 Tahun 2014. Dengan adanya penetapan tariff pengiriman dan penerimaan kargo di Bandar Udara Kualanamu yang tidak wajar dan berubah-ubah karena berubahnya pemberlakuan sebelum Daerah Keamanan Terbatas sampai pemberlakuan Regulated Agent (RA), membuat konsumen menjadi bingung dan merasa dirugikan. Kemudian syarat untuk pengambilan kargo pengiriman dan penerimaan harus melalui Lini 2 membuat konsumen tidak memiliki banyak pilihan karena tingginya harga sewa yang harus ditanggung. Konsumen akan memilih untuk menarik kargonya kembali, karena kenaikan tariff ini tidak ada manfaat apapun bagi konsumen.

Dugaan kesalahan terkait Pasal 17 ayat (1), ayat (2) Undang-undang Nomor 5 Tahun 1999 tentang Praktek Monopoli, yang dilakukan pengelola terkait pelayanan angkutan kargo pos melalui Bandar Udara Kualanamu menjadi dugaan atas pelanggaran Pasal 17 Undang-undang No. 5 Tahun 1999, membahas tentang larangan pelaku usaha dalam melakukan penguasaan atas produksi dan/atau pemasaran barang, yang dapat mengakibatkan terjadinya praktek monopoli dan/atau persaingan usaha tidak sehat. Pelaku usaha yang dimaksud, apabila melakukan pemasaran barang dan/atau jasa yang bersangkutan belum ada subtitusinya, mengakibatkan pelaku usaha lain tidak dapat masuk ke dalam persaingan usaha barang dan/atau jasa yang sama, dan merupakan satu atau beberapa kelompok pelaku usaha yang menguasai lebih dari 50\% (lima puluh persen) pasar satu jenis barang dan/atau jasa tertentu. Dengan adanya Laporan terkait praktek Monopoli tersebut KPPU melakukan penelusuran terkait kasus tersebut, dan memperoleh bahwa bukti-bukti yang ada cukup jelas dan lengkap untuk dikatakan melakukan 
pelanggaran Pasal 17 Undang-undang Nomor 5 Tahun 1999. Dan memberikan hukuman administratif diharuskan membayar denda sebesar enam milyar yang harus disetor ke Kas Negara, serta menurunkan tariff pengiriman kargo dan pos dengan mempertimbangkan seluruh aktivitas yang musnah setelah digantikan oleh regulated agent (RA) dan menempatkan kembali proses pengambilan kargo dan pos di Bandar Udara Kualanamu tanpa melalui Lini 2 dan juga mengembalikan pekerjaan Lini 2 yaitu proses penerimaan pos dan kargo.

Dapat disimpulkan bahwa dalam perkara ini PT Angkasa Pura II (persero) telah melanggar tanggung jawab hukum, telah melanggar tanggung jawab hukum karena dalam melaksanakan kegiatannya, perusahaan korporasi wajib mengikuti peraturan perundangundangan yang telah ditetapkan sebagai rasa tanggung jawab terhadap hukum. KPPU menilai bahwa dengan demikian PT Angkasa Pura II (persero) telah melakukan penyimpangan posisi monopoli dan pelanggaran dengan mengenakan harga yang merugikan masyarakat. Dan hanya mengambil keuntungan sendiri secara sepihak tanpa memperhatikan kebutuhan masyarakat. Oleh karena itu, berdasarkan pendekatan rule of reason yang menganalisis dampak terhadap persaingan, terbuktilah bahwa apa yang dilakukan PT Angkasa Pura II (persero) merupakan Praktek monopoli yang merugikan kepentingan umum dan karenanya dilarang.

\section{SARAN}

Karena dalam perkara ini terjadi pelanggran yang dapat merugikan banyak pihak terutama konsumen, maka kepada para pihak perumus undang-undang untuk merevisi undang-undang yang sudah ada, terutama mengenai pengawasan monopoli terhadap pelaku usaha, serta peranan KPPU dalam memantau segala bentuk pelanggaran yang berkaitan dengan perlindungan konsumen.

\section{DAFTAR PUSTAKA}

\section{Buku}

Muhammad, Abdulkadir. 2004. Hukum dan Penelitian Hukum, PT.Citra Aditya Bakti: Bandung.

Siswanto. Arie. 2004, Hukum Persaingan Usaha, cet 2, Ghalia Indonesia: Bogor.

Fahmi Lubis, Andi, dkk. Buku Teks Hukum Persaingan Usaha Edisi Kedua, Jakarta: KPPU, 2017, 
Fajar, Mukti dan Yulianto Achmad. 2017, Dualisme Penelitian Hukum Normatif Dan Empiris, Cetakan IV, Pustaka Pelajar: Yogyakarta.

Mahmud Marzuki, Peter. 2011. Penelitian Hukum. Kencana Prenada Media Group: Jakarta. Soekanto, Soerjono dan Sri Mamudji. 2001, Peneliitian Hukum Normatif (Suatuu Tinjauan Singkat), Rajawali Pers: Jakarta.

Sugiyono. 2009, Metode Penelitian Kuantitatif, Kualitatif dan R\&D, Alfabeta: Bandung.

\section{Peraturan Perundang-undangan}

Peraturan Menteri Perhubungan Nomor 33 Tahun 2015 tentang Pengendalian Jalan Masuk ke Daerah Keamanan Terbatas.

Undang-undang Nomor 5 Tahun 1999 Tentang Larangan Praktek Monopoli dan Persaingan Usaha Tidak Sehat.

\section{Putusan}

Putusan KPPU Nomor 03/KPPU-I/2017, putus pada tanggal 24 April 2018.

\section{Jurnal Ilmiah}

Bagus Kade Benol Permadi, Ida dan A.A Ketut Sukranatha. "Konsep Rule of Reason Untuk Mengetahui Praktek Monopoli” Jurnal Hukum.

Sanjaya, Indra. 2020, "Penerapan Pendekatan Rule Of Reason Oleh Kppu Dalam Dugaan Pengenaan Harga Eksesif (Studi Kasus Putusan KPPU Nomor Perkara 03/KppuI/2017)", Junal Ilmu Sosial dan Pendidikan Vol. 4 No. 2, 2020.

Puspitasari, Zuhro. 2017, "Rekonsepsi Pengecualiian Monopoli yang diselenggarakan oleh Badan Usaha Miilik. Negara dalam Hukum Persaingan Usaha di Indonesiaa”, Jurnal Panorama Hukum, Vol. 2, No. 2, 2017.

\section{Sumber Internet}

Arti kata Persaingan, < pukul 23:16 